
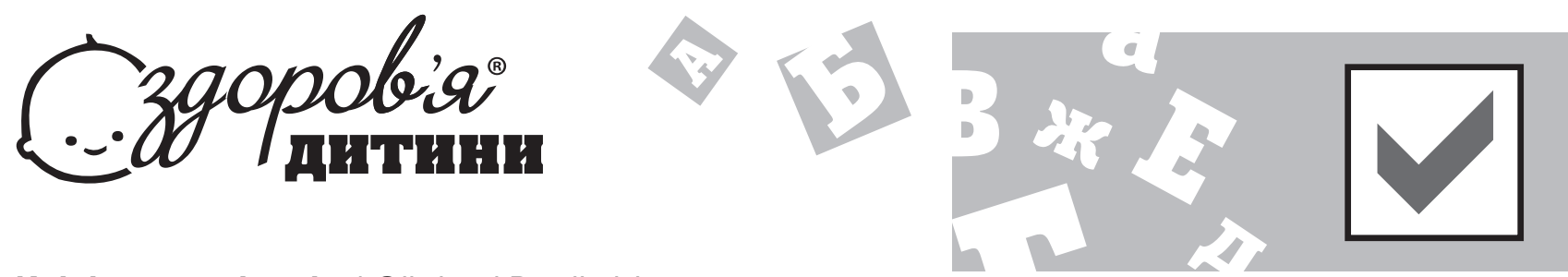

КАінічна педіатрія / Clinical Pediatrics

\title{
Evaluation of psychiatric symptoms of children with Celiac Disease and their relationship with gluten-free diet and maternal factors
}

\author{
For citation: Zdorov'e Rebenka. 2021;16(4):279-284. doi: 10.22141/2224-0551.16.4.2021.236905
}

\begin{abstract}
Background. The purpose was to evaluate the quality of life scores and the adherence of gluten-free diet $(G F D)$ in children with celiac disease (CD). The other objective was to determine the relevance of the maternal emotional status between the psychological adjustments and GFD compliance of the patients with CD. Material and methods. Children's depression inventory (CDI), Screen for Child Anxiety and Related Disorders (SCARED), Strength and Difficulties Questionnaire (SDQ), KINDer Lebensqualitätsfragebogen Questionnaire, Beck Depression Inventory (BDI) and Beck Anxiety Inventory (BAI) were administered to both children with CD healthy controls. Furthmore, the results were compared between the CD patients ant the healthy ones. Results. A total of 47 patients with $C D$, 33 healthy children and their mothers were enrolled. GFD-compliance rate, which was confirmed by antibody tests, was found to be $41.7 \%$. The scores of CDI, SCARED, and $S D Q$ were significantly higher in CD patients than the healthy children. Moreover, the total scores of KINDL was significantly lower in CD group. Higher scores of BDI and BAI were found in the CD patients' mothers than the healthy group. In patients group there were positive-moderate statistically significant correlation detected between score of BDI, BAI of mothers and CDI, SCARED, SDQ scores of children. There were also negative statistically significant correlation between scores of BDI, BAI of mothers and KINDL scores of children. Conclusions. Increased prevalence of psychopathology and reduced quality of life have been clearly demonstrated in children with $C D$. Worse maternal psychosocial adjustment significantly associated with depressive symptoms in pediatric CD patients. Keywords: celiac disease; quality of life; gluten-free diet; psychopathology; children; adolescents
\end{abstract}

\section{Introduction}

Celiac Disease (CD) is a chronic T-cell-mediated autoimmune disease characterized by inflammation and villous atrophy in the small intestines. CD is common autoimmune-genetic disorder, accounting for the $0.5-1 \%$ of general population ${ }^{1}$. Patients with CD suffer from lifelong intolerance to the gluten-containing grains and may present with various symptoms ${ }^{1}$. Only available treatment for now is gluten free diet (GFD) to which strict adherence is essential. Lack of dietary compliance cause a number of gastrointestinal and extra-intestinal symptoms ${ }^{2}$.

Psychological disorders and low quality of life may accompany the disease in patients with $\mathrm{CD}$. Anxiety disorders, social phobia, panic disorder, depression and mood disorders are among the reported psychiatric disorders in these patients $^{3}$. Although adherence to a GFD has been shown to be associated with reduction in depressive symptoms in children with $\mathrm{CD}^{4}$, difficulties in adhering to a GFD may also cause emotional, social, and behavioral problems in these children. Researchers conclude that psychological disturbances and poor quality of life are not only due to malabsorption related nutritional deficiencies but also because of challenges associated with strict dietary restrictions ${ }^{5}$.

Parental influence is important in the development of the child's coping skills and stress management ${ }^{6}$. Moreover children's diet and preferences are influenced by their parents' eating attitudes ${ }^{7}$. Thus, family support, parental attitudes related to GDF and also emotional status of parents are important environmental factors for adherence to a GFD in children with $\mathrm{CD}^{8}$.

In this study we purposed to evaluate the level of psychiatric symptoms and quality of life and their associations with

C) 2021. The Authors. This is an open access article under the terms of the Creative Commons Attribution 4.0 International License, CC BY, which allows others to freely distribute the published article, with the obligatory reference to the authors of original works and original publication in this journal.

For correspondence: Hasret Ayyildiz Civan, MD, Department of Child Health and Diseases, Division of Pediatric Gastroenterology, Hepatology and Nutrition, University of Health Sciences, Bakırköy Dr. Sadi Training and Research Hospital, Zuhuratbaba Mah, Dr. Tevfik Sağlam Cd No: 11, 34147, Bakırköy, Istanbul, Turkey; e-mail: hasretayyildiz@yah00.com; phone number: +905057479765. Full list of authors information is available at the end of the article. 
adherence to GFD in CD diagnosed children. Additionally, effect of maternal emotional status on psychiatric status and GFD adherence of these children was examined.

\section{Materials and Methods Sample}

A total of 47 children and adolescent (aged between 7-17 years) diagnosed with $\mathrm{CD}$ and their mothers were compared with 33 healthy children and their mothers. Parents and children were enrolled in this study after obtainment of verbal and written informed consent. Patients diagnosed with psychotic disorder, mental retardation, bipolar disorder and any other chronic diseases were excluded from the study. The mothers who were not able to read and write were also excluded.

\section{Measures}

Socio-demographic questionnaire. It includes sociodemographic data such as age, gender, GFD compliance (subjective), socio-economical level, educational state of parents, and medical history in family as well as information including schedule of dietary restrictions and laboratory results to obtain objective GFD compliance data.

Children's depression inventory (CDI). CDI is a 27-item self-report measure designed by Kovacs. It has Turkish validity and reliability 9 . High scores indicate increasing depressive states. The cut-off point for the scale was accepted as 19.

Screen for Child Anxiety and Related Disorders-SCARED. The SCARED is a brief self-report assessment designed to screen childhood anxiety disorders by Birmaher (1999) ${ }^{10}$. The validity and reliability of the Turkish version of SCARED performed by Çakmakçı $(2004)^{11}$. SCARED involves 2 forms for parents and children with 41 items each. Higher scores indicate higher anxiety state. SCARED form combined with sub-scales such as somatic/panic anxiety, generalized anxiety, separation anxiety, social anxiety and school phobia. The child form of this scale was used to determine the anxiety levels of the children who participated in our study.

Strength and Difficulties Questionnaire (SDQ). SDQ is a brief screening instrument developed to assess emotional and behavioural problems in children and adolescents by Robert Goodman (1997) ${ }^{12}$. Form consists of 25 statements that combined with 5 sub-scales; attention deficit and hyperactivity, emotional problems, behavioural problems, social problems, and peer problems. A separate score can be obtained for each subscale, and also the "Total Difficulty Score" can be measured with the sum of first four subscales. The validity and reliability of the Turkish version of SDQ performed by Güvenir (2008) ${ }^{13}$. SDQ consists of 2 forms for parents and children. In this study, the parent self-reporting form, in which parents rate emotional and behavioral problems in their children, was used.

KINDer Lebensqualitätsfragebogen. Children Quality of Life Questionnaire. KINDL is a general purpose healthrelated quality of life measurement instrument particularly developed for children and adolescents by Ravens-Sieberer ve Bullinger (1998). KINDL includes different self-report forms for different age groups as well as a form for parental assessment. KINDL consists of 24 items and 6 dimensions including; physical well-being, emotional well-being, selfesteem, family, friends and school. Each dimension includes 4 items. KINDL items are rated from 1 (never) to 5 (always) using a 5-point likert type scale. The scores of the dimensions can be measured separately or the total quality of life score of these six dimensions can be obtained. Scores range between $0-100$. Higher scores indicate good quality of life. In this study, parents were asked to fill in the Kindl-parent form to evaluate the quality of life of their child ${ }^{14}$.

Beck Depression Inventory (BDI). The BDI is a selfreport scale which contains 21 items. It developed by Beck $(1978)^{15}$. Its Turkish validity and reliability version was performed by Hisli (2008) ${ }^{16}$. A total score is computed by summing the scores across items (range 1/4 0-63). The cut-off point for the scale was accepted as 17 .

Beck Anxiety Inventory (BAI). The BAI is a self-report scale designed by Beck (1988) to measure anxiety symptom level ${ }^{17}$. Higher scores indicate higher anxiety state. The validity and reliability of the Turkish version of BAI performed by Ulusoy $(1993)^{18}$.

\section{Statistical analysis}

All the data were analysed with SPSS (Statistical Package for the Social Sciences) software for Windows (v21.0; IBM, Armonk, NY, USA). Individual and aggregate data were summarized using descriptive statistics including mean, standart deviations, medians (min-max), frequency distributions and percentages. Normality of data distribution was verified by Kolmogorov-Smirnov test. Comparison of the variables with normal distribution was made with Student t-test. The variables which were not normally distributed, the Mann Whitney and Kruskal Wallis tests were conducted to compare between groups. Evaluation of categorical variables was performed by Chi-Square test. P-values of $<0.05$ were considered statistically significant.

\section{Results}

A total of 47 children with CD, 33 healthy controls and their mothers included in the study. In patient group, mean age of the children was 12 years (ranged $=6-18), 59.6 \%$ $(n=28)$ of them were girls and $40.4 \%(n=19)$ were boys. The patient and control groups were similar in terms of mean age, gender, mother's age, father's age, father's education, and family structure.

Thirteen of the parents $(28.3 \%)$ reported that they used to prepare specialized meal content to their children, while $24(52.2 \%)$ reported that the content of the meal was the same for all family members.

Patients and parents were questioned in the same interview about the patient's compliance with GFD. Ten $(21.7 \%)$ of the cases reported that they always followed the GFD, while $18(39.1 \%)$ of them reported that they generally followed the GFD. In addition, the GFD-compliance rate, which was confirmed by antibody tests, was found to be $41.7 \%$ in case group. The characteristics of the patients in the CD group regarding diagnosis and dietary compliance are presented in table 1.

Although it was not significant, presence of a psychiatric diagnosis in the $\mathrm{CD}$ group $(25.5 \%)$ was more than the 
control group $(9.1 \%)$. The scores of CDI, SCARED, and SDQ were significantly higher in CD group than the control group. Moreover, the total scores and majority of subscale scores of KINDL was significantly lower in CD group than the control group. Similarly numerous subscales of SDQ and SCARED scales were found significantly higher in CD group. Furthermore, mean scores of BDI and BAI scales were higher in mothers of patients group (table 2).

There were no significant correlation found between the scores of CDI, SCARED, SDQ, KINDL and mean age, disease duration in CD group ( $p>0.05)$. Similarly scores of BDI and BAI scales were not significantly correlated with mean age, disease duration, gender in mothers of patients group. Additionally, the age, gender, and duration of diagnosis had no significant effect on GFD compliance (objective) in the CD group. There were no differences according to the scores of CDI, SCARED, SDQ, KINDL as well as scores of BDI and BAI scales (in mothers) between the cases with and without GFD-compliance (table 3). There were positive-moderate statistically significant correlation detected between score of BDI, BAI in mothers and CDI, SCARED, SDQ scores in children. There were also negative-moderate significant correlation detected between score of BDI, BAI in mothers and KINDL scores in children (table 4).

\section{Discussion}

This study showed that the children with CD have more physiciatric symptoms than the healthy ones.

There are many barriers to compliance with the GFD such as; lack of awareness, social support, family sociocultural characteristics, self-management behaviors, education level, food contamination, inadequate food labeling, health- care system factors and psychological characteristics of patient. Non-adherence rate, which varies with methodology, sample size and sample characteristics, range from 5 to $70 \%$ in published studies ${ }^{19}$. It has been documented that objective and subjective GFD-compliance outcomes are not always similar for the same sample group in CD patients. Machado et al. compared questionnaire scores with IgA-tTG test results in 46 CD-patients (mean age: 17 years). Serological test results revealed that $56.5 \%$ of the CD-patients did not follow a GFD. On the other hand, $60.9 \%$ of the patients reported full GFD compliance, but only $43.5 \%$ presented negative serological test results and $35.7 \%$ of those who reported strict compliance presented positive $\mathrm{IgA}_{\mathrm{AT}} \mathrm{tG}^{20}$. Similarly in our study, ten $(21.7 \%)$ of the cases reported that they always followed the GFD, while 18 (39.1\%) of them reported that they generally followed the GFD. In addition, the GFD-compliance rate, which was confirmed by antibody tests, was found to be $41.7 \%$ in case group. Fifty percent of the patients who proved objectively not to comply with the GFD reported that they generally followed their diet. Moreover, objective GFD compliance was found in only $5 / 18$ of the cases who were reported to "generally follow the diet" by themselves and their parents.

$\mathrm{CD}$ has been associated with an increased prevalence of depressive symptoms and behavioral disorders in children and adolescents particularly before treatment period. Moreover, improvement in psychopathologies has been documented after GFD $^{21}$. Sevinç et al. compared 52 CD-children with 40 healthy children. Researchers reported poor adherence rate $(70 \%)$ to GFD in CD group. Additionally, scores of emotional functioning, social functioning, school functioning, and total psychosocial health scales were sig-

Table 1. The characteristics of the patients according to the diagnosis and GFD compliance

\begin{tabular}{|c|c|}
\hline Parameters & Patient median (min-max), n (\%) \\
\hline \multicolumn{2}{|c|}{ Age at diagnosis } \\
\hline$<6$ years of age & $9(20.5)$ \\
\hline $6-12$ years of age & $28(63.6)$ \\
\hline$\geq 13$ years of age & $7(15.9)$ \\
\hline Disease age (time from diagnosis) & $24(1-120)$ \\
\hline \multicolumn{2}{|c|}{ Meal at home } \\
\hline Same for everyone & $24(52.2)$ \\
\hline Special for patient & $13(28.3)$ \\
\hline Only the bread is different & $6(13)$ \\
\hline Sometimes special for patient & $3(6.5)$ \\
\hline \multicolumn{2}{|c|}{ Compliance to GFD (subjective) } \\
\hline New diagnosed & $2(4.3)$ \\
\hline Never & $2(4.3)$ \\
\hline Sometimes & $14(30.4)$ \\
\hline Usually & $18(39.1)$ \\
\hline Always & $10(21.7)$ \\
\hline \multicolumn{2}{|c|}{ Compliance to GFD (objective) } \\
\hline Present & $20(41.7)$ \\
\hline Absent & $28(58.3)$ \\
\hline
\end{tabular}


nificantly higher in CD group than the control group ${ }^{22}$. Similarly Kara et al. reported an increased levels of anxiety in children diagnosed with $\mathrm{CD}$ and also increased trauma symptoms in their mothers ${ }^{23}$. Giannakopoulos et al. documented significantly higher levels of anxiety and depression in CD patients and their parents than healthy controls ${ }^{24}$. In accordance with these data, the scores of CDI, SCARED, and SDQ were found significantly higher in CD group than the control group in present study. Similarly numerous subscales of SDQ and SCARED scales were found significantly higher in CD group. Mean scores of BDI and BAI scales were higher in mothers of patients group. Furthermore, there were positive-moderate statistically significant correlation detected between score of BDI, BAI in mothers and CDI, SCARED, SDQ scores in children.

Strict dietary restrictions and disease burden may negatively affect children diagnosed with CD. Therefore it is essential to measure quality of life while managing disease and screening the improvements. Stojanović et al. highlighted importance to include both children and parents in QOL measurements. Researchers also noted similar QOL scores and the differences in the scores of SCARED questionnaire between parents and their children ${ }^{25}$. Although significant associations have been documented between QOL and CD in children and adolescents, the findings are still debated ${ }^{26}$. Barrio et al. concluded that CD has no negative impacts on QOL in a study consisting of 1602 children and their parents $^{27}$. On the contrary, Stojanović et al. reported that the mean score of QOL was significantly lower in children with $\mathrm{CD}(\mathrm{n}=116)$ than in the healthy controls $(\mathrm{n}=116)^{28}$. Supportively in present study, the total scores and majority of subscale scores of KINDL was significantly lower in CD group than the control group. There were also negativemoderate statistically significant correlation detected between score of BDI, BAI in mothers and KINDL scores in children. But there were no statistically significant diffe-

Table 2. Comparison of the psychiatric status and scale scores between groups

\begin{tabular}{|c|c|c|c|}
\hline \multirow{3}{*}{ Parameters } & \multicolumn{2}{|c|}{ Groups } & \multirow{3}{*}{$p$-value } \\
\hline & Patients & Controls & \\
\hline & \multicolumn{2}{|c|}{ Median (min-max), n (\%) } & \\
\hline \multicolumn{3}{|l|}{ History of any psychopathology } & \multirow{3}{*}{0.064} \\
\hline Absent & $35(74.5)$ & $30(90.9)$ & \\
\hline Present & $12(25.5)$ & $3(9.1)$ & \\
\hline CDI & $7(2-41)$ & $5(1-18)$ & 0.007 \\
\hline \multicolumn{4}{|l|}{ SCARED } \\
\hline Phobic anxiety subscale score & $6(1-19)$ & $3(0-12)$ & 0.002 \\
\hline Generalized anxiety subscale score & $6(1-15)$ & $2(0-17)$ & 0.001 \\
\hline Separation anxiety subscale score & $6(0-16)$ & $4(0-14)$ & 0.127 \\
\hline Social anxiety subscale score & $7(1-13)$ & $5(0-13)$ & 0.072 \\
\hline School Phobia subscale score & $2(0-8)$ & $2(0-4)$ & 0.466 \\
\hline SCARED-Total score & $37(12-97)$ & $25(7-62)$ & 0.001 \\
\hline \multicolumn{4}{|l|}{ SDQ } \\
\hline Emotional problems subscale score & $4(0-11)$ & $1(0-6)$ & $<0.001$ \\
\hline Behavioural problems subscale score & $2(0-8)$ & $1(0-4)$ & 0.013 \\
\hline Attention deficit and hyperactivity subscale score & $4(0-8)$ & $2(0-7)$ & 0.019 \\
\hline Peer problems subscale score & $3(0-9)$ & $1(0-4)$ & $<0.001$ \\
\hline Social problems subscale score & $1(0-5)$ & $0(0-3)$ & 0.015 \\
\hline SDQ-Total score & $14(0-26)$ & $6(1-17)$ & $<0.001$ \\
\hline \multicolumn{4}{|l|}{ KINDL } \\
\hline Physical well-being score & $70(30-100)$ & $85(45-100)$ & $<0.001$ \\
\hline Emotional well-being score & $80(25-100)$ & $85(70-100)$ & $<0.001$ \\
\hline Self-esteem score & $70(35-100)$ & $85(60-100)$ & 0.001 \\
\hline Family score & $80(30-100)$ & $85(65-100)$ & 0.182 \\
\hline Friends score & $75(35-100)$ & $90(65-100)$ & $<0.001$ \\
\hline School score & $70(40-100)$ & $85(60-100)$ & 0.001 \\
\hline Total QOL & $71(50-96)$ & 84 (69-99) & $<0.001$ \\
\hline Disease score & $73(33-100)$ & - & - \\
\hline BAI & $10(0-48)$ & $4(1-38)$ & 0.010 \\
\hline BDI & $9(0-45)$ & $4(0-18)$ & $<0.001$ \\
\hline
\end{tabular}

Note: $p<0.05$ statistically significant. 
Table 3. Comparison of the GFD compliance status and scale scores in CD patients

\begin{tabular}{|l|c|c|c|}
\hline \multirow{2}{*}{\multicolumn{1}{c|}{ Parameters }} & \multicolumn{2}{c|}{ GFD compliance (objective) } & \multirow{2}{*}{$\boldsymbol{p}$-value } \\
\cline { 2 - 3 } & \multicolumn{2}{c|}{ Present } & \multicolumn{2}{c|}{ Absent } \\
\cline { 2 - 3 } & \multicolumn{2}{c|}{ Median (min-max) } & 0.643 \\
\hline CDI score & $7.5(3-32)$ & $7(2-41)$ & 0.263 \\
\hline SCARED-Total score & $43.5(12-67)$ & $32(13-97)$ & 0.272 \\
\hline SDQ-Total score & $14.5(2-26)$ & $14(0-24)$ & 0.091 \\
\hline Total QOL & $66(54-92)$ & $73(50-96)$ & 0.931 \\
\hline KINDL Disease subscale score & $75(33-100)$ & $73(40-100)$ & 0.219 \\
\hline BAI score & $12.5(0-47)$ & $9(0-48)$ & 0.337 \\
\hline BDI score & $12(0-40)$ & $7(0-45)$ & 0 \\
\hline
\end{tabular}

Table 4. Comparison of the scores of CDI, SCARED, SDQ, KINDL of children and BAI, BDI scores of CD mothers

\begin{tabular}{|l|c|c|c|c|}
\hline \multirow{2}{*}{ Parameters } & \multicolumn{2}{|c|}{ BAI score } & \multicolumn{2}{c|}{ BDI score } \\
\cline { 2 - 5 } & $\boldsymbol{r}$ & $\boldsymbol{p}$ & $\boldsymbol{r}$ & $<$ \\
\hline CDI score & 0.571 & $<\mathbf{0 . 0 0 1}$ & 0.617 & $\mathbf{0 0 1}$ \\
\hline SCARED-Total score & 0.465 & $\mathbf{0 . 0 0 1}$ & 0.514 & $<.001$ \\
\hline SDQ-Total score & 0.566 & $<\mathbf{0 . 0 0 1}$ & 0.667 & $<.001$ \\
\hline Total QOL & -0.491 & $<\mathbf{0 . 0 0 1}$ & -0.546 & $\mathbf{0 . 0 0 1}$ \\
\hline KINDL QOL & -0.346 & $\mathbf{0 . 0 1 7}$ & -0.181 & 0.223 \\
\hline
\end{tabular}

rences found according to the scores of KINDL between the cases with and without GFD-compliance.

Main limitation of this study was the small sample size of the patient group and was including the data from a single center but its' prospective study and the fact that a lot of testing has been done, the inclusion of mothers are the features that will contribute to the literature.

\section{Conclusions}

In conclusion, increased prevalence of psychopathologies and reduced quality of life have been clearly demonstrated in children diagnosed with CD. Particularly inappropriate family attitudes significantly associated with depressive symptoms. On the other hand, lack of GFD compliance has not been related to depressive symptoms or quality of life. Therefore, it is not only crucial to compliance with GFD for children but also essential to awareness of GF lifestyle for family in order to successful management of disease.

\section{References}

1. Caio $G$, Volta $U$, Sapone A, et al. Celiac disease: a comprehensive current review. BMC Med. 2019 Jul 23;17(1):142. doi:10.1186/ s12916-019-1380-z.

2. Di Nardo G, Villa MP, Conti L, et al. Nutritional Deficiencies in Children with Celiac Disease Resulting from a Gluten-Free Diet: A Systematic Review. Nutrients. 2019 Jul 13;11(7):1588. doi:10.3390/nu11071588.

3. Coburn SS, Puppa EL, Blanchard S. Psychological Comorbidities in Childhood Celiac Disease: A Systematic Review. J Pediatr Gastroenterol Nutr. 2019 Aug;69(2):e25-e33. doi:10.1097/ MPG.0000000000002407.

4. Simsek $S$, Baysoy G, Gencoglan S, Uluca U. Effects of GlutenFree Diet on Quality of Life and Depression in Children With Celiac Dis- ease. J Pediatr Gastroenterol Nutr. 2015 Sep;61(3):303-6. doi:10.1097/ MPG.0000000000000799.

5. Biagetti C, Gesuita R, Gatti S, Catassi C. Quality of life in children with celiac disease: A paediatric cross-sectional study. Dig Liver Dis. 2015 Nov;47(11):927-32. doi:10.1016/j.dld.2015.07.009.

6. Wagner $G$, Zeiler M, Berger $G$, et al. Eating Disorders in Adolescents with Celiac Disease: Influence of Personality Characteristics and Coping. Eur Eat Disord Rev. 2015 Sep;23(5):361-70. doi:10.1002/erv. 2376.

7. Knez R, Francisković T, Samarin RM, Niksić M. Parental quality of life in the framework of paediatric chronic gastrointestinal disease. Coll Antropol. 2011 Sep;35 Suppl 2:275-80.

8. Epifanio MS, Genna V, Vitello $M G$, Roccella M, La Grutta $S$. Parenting stress and impact of illness in parents of children with coeliac disease. Pediatr Rep. 2013 Dec 19;5(4):e19. doi:10.4081/pr.2013.e19.

9. Öy B. Reliability and validity of the child depression scale. Turk Psikiyatri Derg. 1991;1:132-136.

10. Birmaher B, Brent DA, Chiappetta L, Bridge J, Monga S, Baugher M. Psychometric properties of the Screen for Child Anxiety Related Emotional Disorders (SCARED): a replication study. J Am Acad Child Adolesc Psychiatry. 1999 Oct;38(10):1230-6. doi:10.1097/00004583199910000-00011.

11. Çakmakçı FK. The reliability and validity study of the screen for child anxiety- related emotional disorders (SCARED). Izmit: Faculty of Medicine, Kocaeli University; 2004.

12. Goodman R. The Strengths and Difficulties Questionnaire: a research note. J Child Psychol Psychiatry. 1997 Jul;38(5):581-6. doi:10.1111/j.1469-7610.1997.tb01545.x.

13. Güvenir T, Özbek A, Baykara B, Arkar H, Şentürk B, incekaş $S$. Psychometric properties of the Turkish version of the strengths and difficulties questionnaire (SDQ). Turk J Child Adolesc Ment Health. 2008;15(2):65-74. (in Turkish).

14. Ravens-Sieberer U, Bullinger M. Assessing health-related quality of life in chronically ill children with the German KINDL: first psycho- 
metric and content analytical results. Qual Life Res. 1998 Jul;7(5):399407. doi:10.1023/a:1008853819715.

15. Beck A, Rush J, Shaw B, Emery G. Cognitive Therapy of Depression, New York: Guilford; 1979. 229-256pp.

16. Hisli N. Beck Depresyon Envanterinin üniversite öğrencileri için geçerliği, güvenirliği [Validity and reliability of Beck Depression Inventory for university students]. Psikoloji dergisi. 1989;7(23):3-13. (in Turkish)

17. Beck AT, Epstein N, Brown G, Steer RA. An inventory for measuring clinical anxiety: psychometric properties. J Consult Clin Psychol. 1988 Dec;56(6):893-7. doi:10.1037//0022-006x.56.6.893.

18. Ulusoy M. Beck anksiyete envanteri: Geçerlik ve güvenirlik çalışması [Beck anxiety inventory: Validity and reliability study]. istanbul: Bakırköy Ruh ve Sinir Hastalikları Hastanesi; 1993. (in Turkish).

19. Holbein CE, Carmody JK, Hommel KA. Topical Review: Adherence Interventions for Youth on Gluten-Free Diets. J Pediatr Psychol. 2018 May 1;43(4):392-401. doi:10.1093/jpepsy/jsx138.

20. Machado J, Gandolfi L, Coutinho De Almeida F, Malta Almeida L, Puppin Zandonadi R, Pratesi R. Gluten-free dietary compliance in Brazilian celiac patients: questionnaire versus serological test. Nutr Clin Diet Hosp. 2013 Jul;33(2):46-49. doi:10.12873/332gluten.

21. Coburn S, Rose M, Sady M, et al. Mental Health Disorders and Psychosocial Distress in Pediatric Celiac Disease. J Pediatr Gastroenterol Nutr. 2020 May;70(5):608-614. doi:10.1097/MPG.0000000000002605.

22. Sevinc E, Çetin FH, Coşkun BD. Psychopathology, quality of life, and related factors in children with celiac disease. J Pediatr (Rio J). 2017 May-Jun;93(3):267-273. doi:10.1016/j.jped.2016.06.012.
23. Kara A, Demirci E, Ozmen S. Evaluation of Psychopathology and Quality of Life in Children with Celiac Disease and their Parents. Gazi Med J. 2019;30(1):43-47. doi:10.12996/gmj.2019.11.

24. Giannakopoulos G, Margoni D, Chouliaras G, et al. Child and Parent Mental Health Problems in Pediatric Celiac Disease: A Prospective Study. J Pediatr Gastroenterol Nutr. 2020 Sep;71(3):315-320. doi:10.1097/ MPG.0000000000002769.

25. Stojanović B, Kočović A, Radlović $N$, et al. Assessment of Quality of Life, Anxiety and Depressive Symptoms in Serbian Children with Celiac Disease and their Parents. Indian J Pediatr. 2019 May;86(5):427-432. doi:10.1007/s12098-018-2836-4.

26. White LE, Bannerman E, Gillett PM. Coeliac disease and the gluten-free diet: a review of the burdens; factors associated with adherence and impact on health-related quality of life, with specific focus on adolescence. J Hum Nutr Diet. 2016 Oct;29(5):593-606. doi:10.1111/jhn. 12375.

27. Barrio J, Román E, Cilleruelo M, Márquez M, Mearin $M L$, Fernández C. Health-Related Quality of Life in Spanish Children With Coeliac Disease. J Pediatr Gastroenterol Nutr. 2016 Apr;62(4):603-8. doi:10.1097/MPG.0000000000000963.

28. Stojanović B, Medović $R$, Đonović $N$, et al. Assessment of quality of life and physical and mental health in children and adolescents with coeliac disease compared to their healthy peers. Srpski arhiv za celokupno lekarstvo. 2019;147(5-6):301-306. doi:10.2298/SARH180222035S.

Received 09.04.2021

Revised 26.04.2021 Accepted 05.05.2021

\section{Information about authors}

Hasret Ayyildiz Civan, MD, Department of Child Health and Diseases, Division of Pediatric Gastroenterology, Hepatology and Nutrition, University of Health Sciences, Bakırköy Dr. Sadi Training and Research Hospital, Istanbul, Turkey; e-mail: hasretayyildiz@yahoo.com; phone number: +905057479765; https://orcid.org/0000-0002-5604-9722.

Semra Y.Imaz, Department of Child and Adolescent Psychiatry and Mental Health; Bakırköy Dr. Sadi Konuk Training and Research Hospital, Istanbul, Turkey; e-mail: semrayilmaz@yahoo.com; https://orcid.org/0000-0002-6527-2432.

Conflicts of interests. Authors declare the absence of any conflicts of interests and their own financial interest that might be construed to influence the results or interpretation of their manuscript. Informed consent. Informed consent was obtained from all individual participants included in the study.

Ethical approval. The study was reviewed and approved by the local ethical review committee of dr. Sadi Konuk Education and Research Hospital.

Funding sources. No specific funding was received from any funding bodies in the public, commercial or not for-profit sectors to carry out the work described in this manuscript.

Acknowledgements. All the authors have approved this submission. Civan H.A. — conceptualization, study design, supervision, data curation; Semra Yılmaz — data analysis, writing, language translate.

Hasret Ayyıldız Civan, Semra Yılmaz

Bakırköy Dr. Sadi Konuk Training and Research Hospital, м. Стамбул, Туреччина

\section{Оцінка психіатричних симптомів у Аітей із целіакією та їх зв'язок із безглютеновою Аієтою та материнськими факторами}

Резюме. Актуальність. Мета дослідження: оцінити показники якості життя та прихильності до безглютенової дієти (БГД) у дітей із целіакією. Крім того, визначали значущість емоційного статусу матері з погляду психологічної корекції та відповідності призначення БГД пацієнтам із целіакією. Матеріали та методи. Дитячий опитувальник депресії (CDI), скринінг на тривожність і пов'язані з нею розлади в дітей (SCARED), опитувальник сили і труднощів (SDQ), опитувальник KINDer Lebensqualitätsfragebogen, шкала оцінки депресії Бека (BDI) i шкала оцінки тривожності Бека (BAI) були використані як у дітей із целіакією, так і у здорових дітей. Крім того, результати були зіставлені між пацієнтами 3 целіакією і здоровими учасниками дослідження. Результати. До дослідження ввійшли 47 пацієнтів із целіакією, 33 здорові дитини та їх матері. Рівень відповідності БГД, який був підтверджений тестами на антитіла, становив 41,7 \%. Показники шкал CDI, SCARED та SDQ були значно вищими в пацієнтів із целіакією, ніж у здорових дітей. Крім того, загальні бали за KINDL були значно нижчими в групі учасників із целіакією. Більш високі показники шкали оцінки депресії Бека та шкали оцінки тривожності Бека були виявлені в матерів пацієнтів із целіакією, ніж у групі здорових дітей. У групі пацієнтів із целіакією була виявлена позитивна помірна статистично значуща кореляція між показниками шкали оцінки депресії Бека, шкали оцінки тривожності Бека і CDI, SCARED, SDQ. Також спостерігалася негативна статистично значуща кореляція між показниками шкали оцінки депресії Бека, шкали оцінки тривожності Бека в матерів і показниками за шкалою KINDL у дітей. Висновки. Підвищена поширеність психопатології та зниження якості життя були чітко продемонстровані в дітей із целіакією. Погіршення психосоціальної адаптації матері значною мірою пов'язане 3 депресивними симптомами в дітей із целіакією.

Ключові слова: целіакія; якість життя; безглютенова дієта; психопатологія; діти; підлітки 